Marek Mutor dyrektor Ośrodka "Pamięć i Przyszłość" we Wrocławiu. Polonista i historyk, absolwent Uniwersytetu Wrocławskiego. Szef Narodowego Centrum Kultury w latach 2006-2007 oraz w 2016 r. W latach 2002-2009 radny Rady Miejskiej Wrocławia, a w latach 2006-2007 jej wiceprzewodniczacy. Twórca państwowych programów m.in. "Patriotyzm Jutra”, "Świadkowie Historii". Organizator wystaw, m.in. "Pociag do historii" czy "Solidarny Wrocław". Twórca Centrum Historii Zajezdnia.

\section{Trzeba skończyć z bytami pozorowanymi}

Z Markiem Mutorem rozmawia Rafał Nowakowski

Rafał Nowakowski: Od 25 lat funkcjonuja we Wrocławiu rady osiedli, jednostki pomocnicze gminy. I od ćwierćwiecza nie milkna dyskusje i spory, w jakim kierunku powinny podążá reformy tych rad. W czerwcu 2008 r. przedstawił Pan - jako współautor - projekt reformy wrocławskich jednostek pomocniczych. Ale prace zaczęły się o wiele wcześniej? Marek Mutor: Prace rozpoczęły się w 2007 r. wraz z utworzeniem Stowarzyszenia „Dolny Śląsk XXI" i ruchu samorządowego o tej samej nazwie. Działania te wywołały dyskusję merytoryczną o samorządzie w ogóle, bo stowarzyszenie tworzyli ludzie wywodzący się z samorządu, o proreformatorskim nastawieniu. Byłem inicjatorem tego przedsięwzięcia, ale brało w nim też udział wielu radnych, m.in. Szymon Hotała, Henryk Macała, Jan Styś i inni. Wszyscy wyrośli z rad osiedli, mieli więc krytyczny osąd na temat ich działania. Wiedzieliśmy na pewno, że rady osiedli w dotychczasowym kształcie to niewykorzystany potencjał, fasadowy organizm o nikłych zadaniach i kompetencjach, utworzony na okres przejściowy. Na początku lat dziewięćdziesiątych XX w. były one tworzone w opozycji do ówczesnych nomenklaturowych pięciu dzielnic powiązanych z dawnym systemem. Ten ruch od strony politycznej wybranego w 1990 r. samorządu był zrozumiały. Ale po prawie dwudziestu latach tak utworzone jednostki pomocnicze nie spełniały istotnej roli, co dobitnie potwierdza do dziś bardzo niska frekwencja w wyborach do rad osiedli. Rady nie miały nigdy realnych kompetencji i zadań. Mają jedynie kompetencje opiniodawcze, ale ich opinie bardzo często nie były honorowane przez władze miasta i urzędników. To potęgowało frustracje, które były nam dobrze znane. Z tej diagnozy wyrósł więc pogląd, że należy to zmienić, a mandat, jaki otrzymaliśmy od wyborców, dawał nam taką możliwość. Wniosek ten wyrastał także z kontekstu dynamicznego rozwoju Wrocławia, co symbolizowały przygotowania do Euro 2012, starania o organizację EXPO czy duża liczba inwestycji

Miasto. Pamięć i Przyszłość 1 (2016) ISSN 2543-621X 
stymulowanych przez środki europejskie. W mojej ocenie władze miasta, co naturalne w takiej sytuacji, skoncentrowały się na dużych projektach inwestycyjnych, podczas gdy gros spraw, nazwijmy je "lokalnych - osiedlowych", zaczynało umykać optyce Ratusza. Realne decyzje w tych sprawach spłynęły na niższe instancje w administracji miejskiej, pozostawały poza głównym nurtem debaty w Radzie Miejskiej. A to właśnie te drobne sprawy przesądzają nierzadko o jakości życia.

R.N.: Czyli samoistnie wyłonił się model podziału kompetencji na ogólnomiejskie, dedykowane samorzadowi miasta, i te lokalne, zarezerwowane dla osiedli.

M.M.: Problemy lokalne są zauważalne przez władze samorządowe poprzez działanie poszczególnych radnych, którzy dzięki swojej pozycji są w stanie załatwić na przykład remont konkretnej drogi osiedlowej. Sprawy te zapisuje się w budżecie miasta często w ogólnych pozycjach, a ich wykonanie zleca jednostkom miasta. Wybór konkretnych zadań odbywa się na poziomie tworzenia układów wykonawczych do budżetu. A zatem są tam wprowadzone te zadania, które zorientowany radny miejski umie z urzędem „wynegocjować". Ale to właśnie nie powinno tak działać. Decyzje w takich sprawach powinny być scedowane do rad osiedlowych, gdzie byłaby szansa na realną debatę i decyzję, które zadania są realizowane, a które muszą poczekać. Zawsze bowiem można zrealizować tylko niewielką część z tego, co warto byłoby zrobić. Dziś konkretne decyzje w zakresie zadań lokalnych zapadają w zaciszu urzędu. A powinny być podejmowane w gronie reprezentantów społeczności, której dotyczą. Krótko mówiąc, pomysł polegał na oddaniu przez władze miasta pewnych kompetencji decyzyjnych (ale nie wykonawczych!) wyłonionym demokratycznie władzom jednostek pomocniczych. Żeby mogło to działać efektywnie, liczba 48 rad osiedli musiałaby ulec redukcji. Wyobrażaliśmy sobie, że optymalna liczba jednostek pomocniczych powinna wynosić 15. Chcieliśmy też nazwać je dzielnicami. Za kryteria posłużyły nam: demografia oraz układ przestrzenny i urbanistyczny. Ponadto braliśmy pod uwagę naturalne granice, jak rzeki, arterie komunikacyjne, trakcje kolejowe, ukształtowanie terenu, etc. Chcieliśmy, aby jednostki te były odpowiednio duże, a przez to i silne. Ich mniejsza liczba ułatwiać miała prowadzenie dialogu. Przy „mapowaniu” nowych dzielnic korzystaliśmy z doświadczeń Krakowa, który ma ich 18.

R.N.: Kilka lat temu krakowscy radni z klubu Platformy Obywatelskiej proponowali utworzenie dodatkowych 17 solectw w peryferyjnych dzielnicach Krakowa, aby w ten sposób

Miasto. Pamięć i Przyszłość 1 (2016) ISSN 2543-621X 
móc korzystać ze środków Programu Rozwoju Obszarów Wiejskich. Chodziło o 10 mln zł na inwestycje infrastrukturalne w mieście. Ale wracajac do naszego tematu, jaki był stosunek radnych osiedlowych do Waszej koncepcji?

M.M.: Z przykrością muszę przyznać, że nie spotkała się z ich akceptacją. Wydaje mi się że nie do końca ją zrozumieli. Z perspektywy czasu oceniam, że nie potrafiliśmy skutecznie przekonać do naszej koncepcji,-źle ją prezentowaliśmy. Dlatego nasz pomysł nie spotkał się ze zrozumieniem. W Radzie Miejskiej obawiano się dalszej utraty realnego wpływu i pozycji, która i tak od 2002 r. uległa znacznemu ograniczeniu na rzecz prezydenta. Dla radnych brak możliwości „wynegocjowania” w urzędzie spraw dla osiedla był postrzegany jako umniejszenie ich roli. Z kolei radni osiedlowi podnosili argument - moim zdaniem niesłuszny - że przy tak dużych jednostkach pomocniczych i zwiększonych kompetencjach dojdzie do szybkiego ich upolitycznienia, a więc staną się one obiektem rywalizacji partii i ugrupowań politycznych. Postawa prezydenta była ostrożna, na początku dał pomoc dla rozpoczęcia prac, ale bez wyraźnego wsparcia dla samej idei.

R.N.: A przecież dla Was poparcie i zrozumienie proponowanych zmian było kluczowe ze względu na planowane wybory do jednostek pomocniczych w I kwartale 2009 r., które chcieliście przeprowadzić do nowych rad dzielnicowych w oparciu o nowa ordynacje, tj. w okręgach jednomandatowych!

M.M.: Radni nie zdecydowali się nawet, aby projekt reformy wszedł do porządku obrad. Tym sposobem temat został odłożony ad acta.

R.N.:A szkoda, bo czytajac projekt statutu dzielnicy przyszłej jednostki pomocniczej, zakładaliście wiele ciekawych i wartych uwagi rozwiq̨zań. Umożliwialiście np. nadawanie różnych, a nie zunifikowanych statutów dzielnic...

M.M.: Była to próba uruchomienia w dzielnicy mechanizmu pobudzającego starania o nowe czy też dodatkowe kompetencje. Oczywiście, niosło to ze sobą zagrożenie powstawania sporów, ale w naszej opinii mogło uwolnić pozytywną energię. Miasto miało stworzyć ramy do ubiegania się o dodatkowe kompetencje. Czyli wracając do wcześniejszego przytoczonego wątku, władze miasta powinny zajmować się sprawami ogólnomiejskimi, a sprawy życia codziennego powinny być przekazane do jednostek pomocniczych. W tym układzie władze miasta miały delegować uprawnienia w oparciu o wnioski rad dzielnicowych. Rady dzielnic miały być włączone w proces zarządzania miastem w zakresie decyzyjnym, a nie wykonawczym. Do tego ostatniego rady nie miały

Miasto. Pamięć i Przyszłość 1 (2016) ISSN 2543-621X 
bowiem fachowego aparatu administracyjnego. Czyli miało to być pośrednio poddanie władz miasta większej kontroli demokratycznej w procesie decyzyjnym. Taką rolę pełni po części obecnie Wrocławski Budżet Obywatelski. WBO to budżet alternatywny, realizowany głosami „ludu”. De facto jest to swoisty plebiscyt. Gdyby do tego dołożyć także budżety wypracowane w systemie rad dzielnic, mielibyśmy dobry, spójny system, równoważący różne lokalne interesy.

R.N.: Wracając do tematu, chciałbym przywołać inne lansowane rozwiq̨zanie w ramach przyszłej reformy jednostek pomocniczych, czyli utworzenie wydziałów i działów na szczeblu miasta i dzielnicy z oddelegowanymi pracownikami samorzadowymi. Wydaje się, że to rozwiq̨zanie, dość odważne, spotkało się z największą krytyką.

M.M.: W układzie 15 dzielnic, które proponowaliśmy, chcieliśmy, aby był im przydzielony niewielki aparat administracyjny, złożony z kompetentnych urzędników zatrudnianych przez Urząd Miejski (a więc prezydenta). Do ich obowiązków należałoby przygotowanie projektów uchwał, obsługa prawna, ale także przyjmowanie i prowadzenie spraw mieszkańców. W strukturze Urzędu Miejskiego powstać miał Wydział Dzielnicowy, który delegowałby pracowników do działów tworzonych na szczeblu dzielnic.

R.N.: A jak zamierzaliście rozwiązać kwestie finansów i budżetów tych dzielnic?

M.M.: Ustawa o samorządzie gminnym przyznaje jedyną i wyłączną kompetencję radzie gminy do uchwalania budżetu. Nasz mechanizm był prosty. W budżecie miasta powinna znaleźć się pozycja: zadania lokalne. Ale jakie to są konkretnie zadania, co się na nie składa, uszczegóławiają załączniki dzielnicowe. Załącznik dzielnicowy to nic innego jak zestawienia zadań lokalnych dla dzielnicy. Każda rada dzielnicy uchwalałaby załącznik dotyczący zadań lokalnych ze swojego terenu w ramach limitu środków ustalonego przez prezydenta. Załączniki trafiałyby do Rady Miejskiej wraz z projektem uchwały budżetowej. Oczywiście, zestawienia zadań lokalnych uchwalone przez dzielnice mogłyby być całkowicie zmienione przez Radę Miejską, bo to jej autonomiczne uprawnienie. Niemniej w Radzie Miejskiej musiano by znaleźć bardzo ważkie argumenty, żeby „wywracać” propozycje dzielnic. Przez ten zabieg rada dzielnicy miała mieć istotny wpływ w procesie decyzyjnym na alokację środków budżetowych przeznaczonych na zadania lokalne.

R.N.: Wróćmy jeszcze do okręgów jednomandatowych...

Miasto. Pamięć i Przyszłość 1 (2016) ISSN 2543-621X 
M.M.: To bardzo ważne, a niestety wówczas było mało zrozumiałe. Zawarte w projekcie okręgi jednomandatowe sprawiały, że argument radnych osiedlowych, iż do rad wejdzie polityka, był bezzasadny. Miasto liczące 600 tys. mieszkańców, podzielone na 15 dzielnic to średnio 40 tys. mieszkańców na dzielnicę. Wybierając 21 radnych w dzielnicy, mamy średnio mniej niż 2 tys. mieszkańców na jednego radnego. W praktyce to maksymalnie 1500 wyborców. Przy frekwencji nawet 50\% w okręgu - głosuje 750 osób. Przy tym trybie wyborów szyld partyjny nie ma znaczenia. Radny dzielnicy to musiałby być człowiek osobiście znany wyborcom, wywodzący się ze środowiska lokalnego, a nie z rozdania politycznego.

\section{R. N.: Jak dziś po latach ocenia Pan wasze działania? Satysfakcja? Poczucie niespełnienia?} M.M.: Mam poczucie, że pracowałem przy ważnym projekcie. I chociaż że sprawa zakończyła się fiaskiem, to udało nam się jednak włączyć ją do debaty publicznej.

\section{R.N.: Czy ma Pan jakieś refleksje na koniec?}

Na pewno należy dążyć do zmiany obecnego status quo, jeśli chodzi o jednostki pomocnicze miasta. Trzeba skończyć z bytami pozorowanymi. A takim są de facto dzisiejsze osiedla. Nie mam gotowych pomysłów. Ale potrzeba zapału i konsekwencji w działaniu, a także nagłośnienia w mediach. Może dobrym pomysłem byłoby poddanie sensu i kierunków reformy jednostek pomocniczych pod referendum lokalne? Mimo wszystko oceniam, że praca w radzie osiedla dała mi spore doświadczenie i wiedzę, co procentowało później w Radzie Miejskiej.

\section{R.N.: Dziękuję za rozmowę.}

